American J. of Engineering and Applied Sciences 3 (3): 576-587, 2010

ISSN 1941-7020

(C) 2010 Science Publications

\title{
Ethnography-Architecture in Kampong Kauman Semarang: A Comprehension of Cultural Toward Space
}

\author{
${ }^{1}$ B. Atiek Suprapti, ${ }^{1}$ Eko Budihardjo, \\ ${ }^{2}$ Nurdien H. Kistanto and ${ }^{3}$ Aristotulus E. Tungka \\ ${ }^{1}$ Department of Architecture, \\ ${ }^{2}$ Department of English, \\ Diponegoro University, Semarang, Indonesia \\ ${ }^{3}$ Department of Architecture, Sam Ratulangi University, Semarang, Indonesia
}

\begin{abstract}
Problem statement: During the last fifty years, there have been significant changes on the perspectives of space. Space definition not only involves physical features but also deals with social capital for human development. Regarding this matter, the research puts the perspective of space as a subject or as a work of art that needs better comprehension rather than considering it as merely an object or fact. Kampung Kauman is a traditional Moslem village located around the Grand Mosque in some cities of Java. In the city of Semarang, Kauman area is an expression of human culture built up over times and experiences for three centuries. Approach: The study applies investigative-method on the transcendental aspects of space by using ethnography-architecture. The classification of ethnography-architecture concentrates on single case. The method applies approaches on culture and design and also participant observation as research tools which will be concluded with open themes. Results: After observing Kauman Pompa Semarang, the research discovers local concepts of 'the charity space' and 'the social intensive space'. Conclusion: The research is a unique knowledge for architecture since the approach on culture reveals the role of Islamic culture in establishing kampung Kauman (Kauman village). Ethnography-architecture is applicable to other researches in investigating the original space concept.
\end{abstract}

Key words: Ethnography, architecture, community

\section{INTRODUCTION}

Lefebvre (1998) explains the production of space. There is dichotomy of space between dominated space and appropriated space. Considering the dominated space, it is a space which is transformed and mediated by technology and by practicing in modern world, instance immediately intelligible. While appropriated space is a natural space modified in order to serve the needs and possibilities of a group that it has been appropriated by that group that it has been appropriated by that group. Considering the above definition, Kampung Kauman has a significant classification of the appropriated space. Kauman people are devout Javanese Moslems. They built Kauman based on their way of life as a place to dwell and propagate the religion of Islam to the people living downtown around the Grand Mosque. Space of Kauman, constructed by social relation over times and history of the people, greatly resembles a work of art. Thus, referring to Lefebvre (1998), the comprehension of space cannot be separated from the understanding of rhythms, time and life included in the experience of space itself (Tuan, 1977).

Generally, research in architecture is related to the exploration of the formal form such as composition, structure (proportion, scale, rhythm) and function (social relation) that applies positivistic method. Here, generalizing social research in positivistic method tends to produce certain knowledge that eventually restricts other thoughts (Denzin, 2009). Obviously, in order to understand the reality of human life, the researchers apply qualitative method to investigate the transcendental aspect of the community. The objective of the research is to investigate the original concept constructed by space symbols. Hence, the researchers use ethnography-architecture to achieve the objective of the study. Ethnography-architecture describes the cultural phenomenon of space structure constructed by social relation from the perspective of the actors.

Corresponding Author: B. Atiek Suprapti, Department of Architecture, Diponegoro University, Semarang, Indonesia 


\section{MATERIALS AND METHODS}

Ethnography-architecture: Ethnography (Ethos from Greek which means people or citizen and graphien which means writing) is a methodological strategy used to provide description of social humanitarian problems. It emphasizes on the perspective of the actor in seeing the world as it appears to others and in understanding the subjectivity of others (Jessor et al., 1996). Ethnography is now used to describe both ethnography as a practicefieldwork in which participant observation is central, but which may also include other approaches such as interviews and qualitative surveys (Atkinson et al., 2008).

The purpose of ethnography-architecture is to discover thought hidden behind the symbol (Geertz, 1973). Culture and architecture are inseparable in which learning both matters will deliver us to the science of symbol referring to certain thought. Thus, researcher should uphold great appreciation toward space as the product of culture built on the basis of social convention. Space here refers to the space having unique and specific pattern with certain structural system (Geertz, 1973). The researcher also tries to comprehend the philosophy of life of the society (Rapoport, 1977). Therefore, communication becomes an important medium upon the transfer of value (Rapoport, 2005). Ethnography-architecture research on space also limits social problem of single space and explores architectural space in detail. It includes sociocultural life of the community, the real terms of the space, the elements of space tools, the arrangement of space structure and the relation among elements of space that constructs the meaning of space.

\section{Research analysis steps:}

Grand tour: (Preliminary Observation) (Fig. 1): Preliminary observation on field (grand tour) is also called descriptive observation. Initially, observation over the entire area is conducted in order to have initial description of the entire area of research (Fig. 1) where main activities and spaces are located. While doing descriptive observation, the researchers are guided by three main questions; (1) what kind of individuals are they? (2) what do they do? and (3) what is the physical realization of space in that social situation?

The steps on grand tour phase are below.

Finding the social situation of space: The intended social situation of space is a particular area that covers specific socio-cultural life of a group of societies (Spradley, 2007). After gaining social situation to be observed, participant observation is therefore conducted. Here, participant observation involves two significant matters; (a) viewing and listening systematically and then focusing on the social situation of space, (b) making notes on every detailed information that is heard and viewed while conducting participant observation. The researcher participates in the regular level. It means the researcher has to maintain his/her complementary position as both insider and outsider and also as both participant and observer.

Making note and documentation: The researcher makes notes to record the social situation of the space, building and environment supported by instruments, such as tape/video recorder, camera, measuring tape (the use of modern tools should be considered carefully in order to acquire natural result). Below are types of data/information:

- Socio-cultural phenomenon information: what do Kauman people do? Why does it happen? What is the background? Who are involved? Where did they do it? What do people feel about it? When did it happen?

- Data of physical elements. It comprises building and space feature elements. What space do they use? Why do they use it? How is the condition? How do people manage it? How is the relation to other elements?

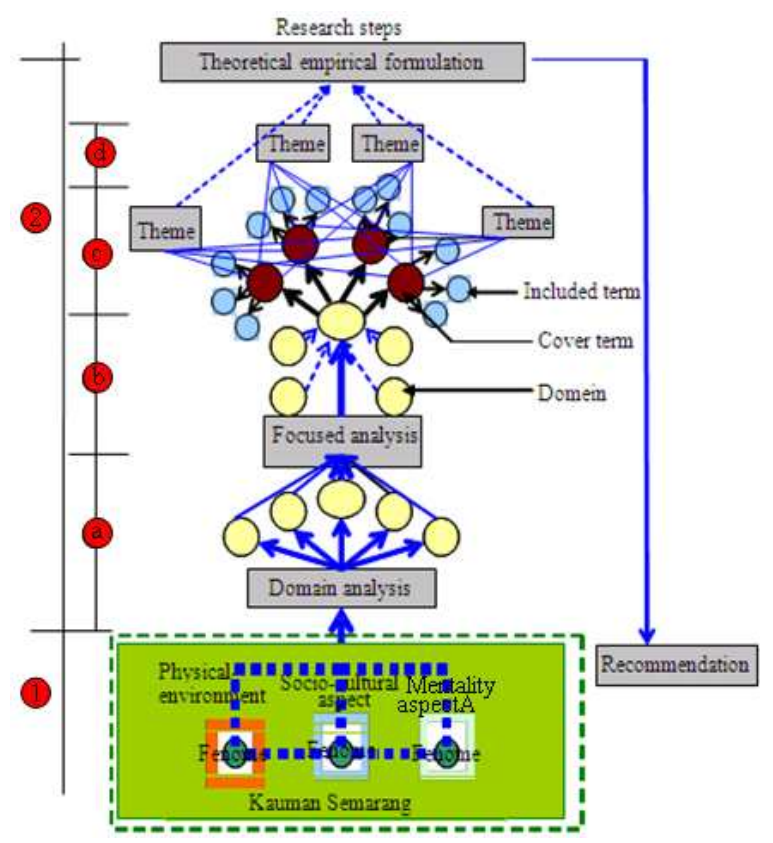

Fig. 1: The diagram of research steps, (Suprapti, 2009) 
Whereas the documenting of physical element is concluded by implementing some steps below:

- Visual photography, to complete data of building and space

- Measuring of territorial space object to gain space and building dimension

- Describing space, building and environment, in picture of different situation, views, pieces, sketches, detailed pictures. The picture of changing situation of space management is required to track the pictures of past objects: solid and void pattern, patterns of public and private, patterns of circulation

- The blueprint of the building is used to indicate the existence of buildings, distribution of facilities, the relation between space and pattern related to city planning

- Field note is distinguished by: (a) short note which is made right after observation, (b) explanation note which is used to explain short note, (c) Field journal (log book), (d) analysis and interpretation. Subsequently, the coding upon each element is conducted to explain data characteristic

\section{Deep observation (mini tour):}

Domain analysis: Space domain is a category of empirical space meaning which includes a smaller number of categories. According to Spradley (2007), some steps need to be arranged to discover the domain. First, initial domain needs to be discovered in order to find the names of original domain. Second, domain analysis is required to find other domains and to examine the hypothesis, whether it will support or weaken the hypothesis. Third, arranging structural questions. Fourth, conducting semantics relation analysis which is aimed at giving direction to the meaning of culture. Semantics relation here means the relation of the capacity inside such matter. In the domain, there are smaller categories, called sub domain, that possess their own rules. Sub domain is one category of space culture knowledge.

Focused analysis: Focused analysis is required to have a deeper observation toward the previous domain observation stage. Some considerations should be taken regarding focused analysis: (1) research focus, (2) information from the informants, (3) theory (Spradley, 2007). After determining one focus of observation, research focus should be directed to focus observation by analyzing symbols.

Taxonomy analysis: Taxonomy analysis refers to the internal structure of the domain. Its objective is to find the arrangement principles (taxonomy) of the original terms in the domain. Taxonomy is a set of category arranged based on a single semantics relation. Taxonomy shows the relation among the original terms in one domain. The original terms in this domain come from the relation among the original terms.

Taxonomy analysis is divided into two kinds of analysis (Spradley, 2007):

- Observation analysis: This is the phase when interview is conducted. The meaning of the original terms can be found by looking at the relation between one original term to another original term in one domain. There are two important principles here; similarity principle and contrast principle

- Componential analysis: Component analysis is a systematic search of the component of space meaning which is frequently connected to symbols

Here, in the ethnography-architecture, the relationship among symbols is focused mostly to the spatial aspect. The researcher not only narrates symbols gained from the informants, but also presents those symbols in the forms of pictures/ sketches, diagrams/ spatial relationship. The meaning itself can be acquired by asking the informants. Several principles of architectural symbols that can be used to discover meaning include:

- Functional principle: The relationship between function and environment (other functions, climate, society), the functional relationship upon spatial structure, the composing elements, the management and convention

- Social convention principle: How symbols possess backgrounds such as idea, purpose, activity/function, physical appearance

- History: how the relationship between symbols and the past is seen (political and economical background when the symbols were created)

Theme: The cultural theme of space is a repeated cognitive principle in a number of domains which happens in a hidden or open way and is considered as the relationship among the systems of meaning branches (Spradley, 2007). Cognitive principle generally takes trusted question which is considered to be true. If there are questions in more than one domain in the cultural context, there will be possibility that the meaning here referred to one cultural element of space.

Theme is an empirical indicator that is concluded by using the field data. After meanings were grouped in themes, it is time to categorize themes into several concepts. Concept is the result of empirical theme 
containing information. In order to get concept, researcher identifies the theme upon the attribute to find out the characteristic of theme and idea so that the thought that forms the background of theme is acquired.

Locus of Kampong Kauman (Kauman Village): Indonesia is a country in which most of the populations are Moslems. They develop their own settlements scattering over cities and towns. Among those Moslem settlements, kampung Kauman (Kauman village) is one of the interesting Moslem settlements that lies around the Masjid Agung (the Great Mosque) in the cities of Java. Kampung Kauman is dwelled by a group of Moslem society bonded in kinship relationship. The dwellers actively execute the law of Islam and propagate the religion through the education of morality. Previously, Kampung Kauman of Semarang city (Fig. 2) does not have an important role. The settlement has developed its role as part of important business sectors in Semarang. Kampung Kauman of Semarang is different from other Kampung Kauman in Java. The one in Semarang endures capital pressure from the central business district surrounding it. This space phenomenon indicates social situation of Semarang Kauman Moslem settlement.

For the "Grand Tour", the researcher is actively involved and fused in many activities of Kauman community; from one event of ceremony to another; from child religious activities to adult religious activities, as a way to get natural experiences toward the setting of space of Kauman Semarang.

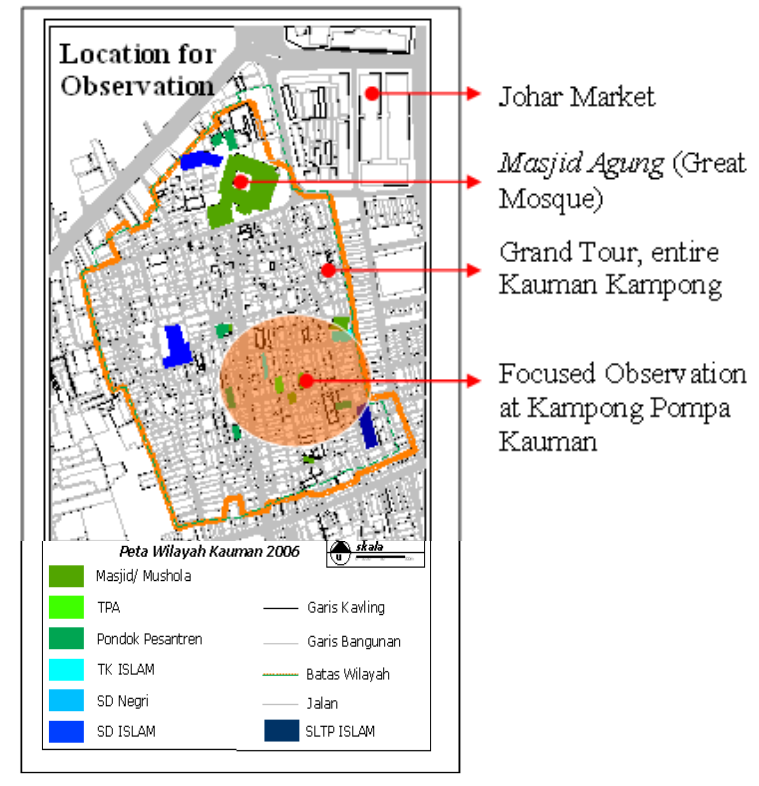

Fig. 2: The location for observation

\section{RESULTS}

Kampung Kauman is the dwelling of faithful Moslems located nearby the Great Mosque in Semarang city of Java. The dwelling is different from other kampung (villages) since Kampung Kauman holds strong ideology of Islam. The people living in kampung Kauman Semarang have developed their lives through self-learning for more than three centuries. Kauman Semarang is influenced by business district activities as it is located downtown. The kampung is also highly shaped by the function of the Great Mosque as the centre of Islamic propagation in the city.

By doing grand tour, the researcher discovers specific activities, places and people doing various activities in different places. The domains found in kampung Kauman Semarang include: (1) familial kinship places, (2) housings, (3) worship places, (4) Religious and moral education places and (5) working places. From the five domains mentioned above, domain 4 (religious and moral education places) has three sub-domains consisting of children Qur'an school, adult Qur'an reading group and Islamic school. Subdomain here is a smaller category of a symbol, such as school building, the manager dwelling house, open space, Qur'an students, board of school, Islam teachers, benefactors and others. There is a certain relationship between sub-domain and symbol. The relationship possesses certain pattern of characteristics, such as: functional, technical, spatial, structural, social, spiritual, identity and others.

The process of Ethnography-Architecture (Fig. 3) focuses on Taman Pendidikan Al-Qur'an/TPA (Qur'an School for children). In this research, focused analysis is determined after conducting grand tour. After finding five domains (Fig. 4), the researcher decided to conduct a focused analysis toward kampung Pompa Kauman which has strong ethnic characteristic and represents all domains of Kauman (Fig. 2).

The most dominant domain is the Religious and moral Education place. This place offers various model of religious and moral education ranging from the traditional model to the modern ones. Therefore, the researcher pointed domain 4 of religious and moral education place. Domain 4 consists of three subdomains: (1) Islamic School of Sultan Agung, (2) Qur'an School for Children (TPA), (3) Pondok Pesantren (Islamic School in which students live in the dormitory during their study period). The most significance domain is Qur'an School for children (Taman Pendidikan Qur'an) which consists of four Cover Terms (CT) and several Included Terms (IT) in every CT. 


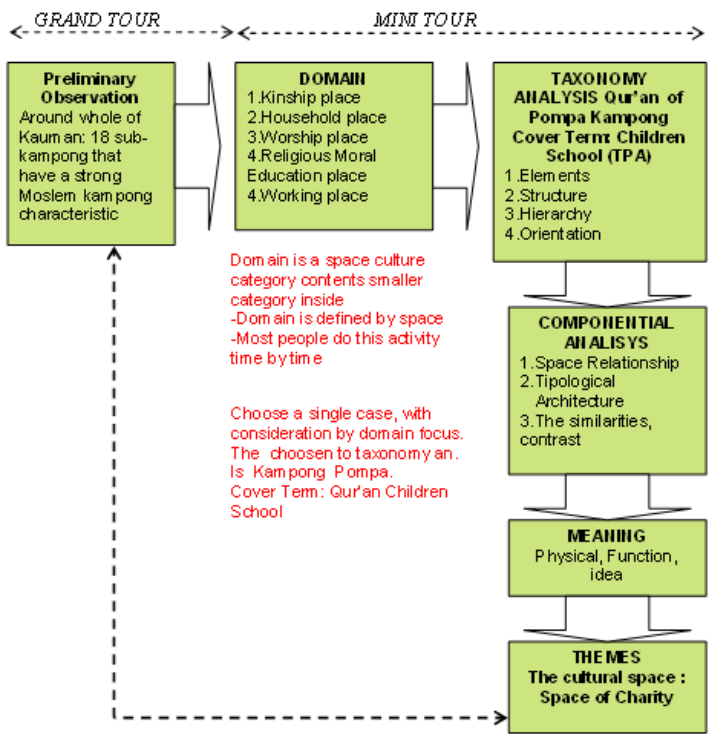

Fig. 3: The process of Ethnography-Architecture focused on Quran Children School (TPA) kampung Pompa Semarang

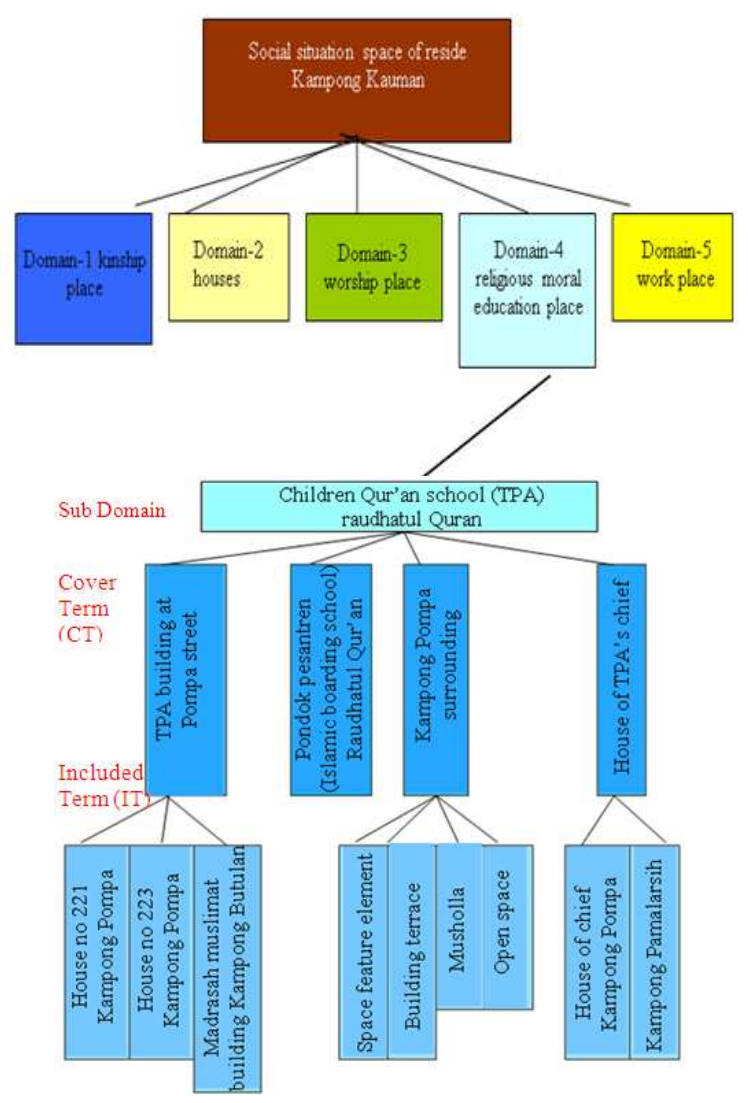

Fig. 4: Diagram of the domain and the sub-domain of the research of Kampung Kauman
The IT involves; buildings of Kampung Pompa (Pompa village), buildings of kampung Butulan (Butulan village), House of Kyai ("Kyai" is a Moslem leader/priest), Musholla Al-Iman (Al-Iman mosque), Raudhatul Qur'an-Qur'an School for Children (Fig. 3).

The five domains found in Kampung Pompa requires flexibility in looking at the area borders of this focused analysis since the area may be wider due to the reality in the field. The next step is documentation which covers; (1) the map of the spreading of the buildings based on the period of establishment, (2) the condition of recent space architecture (site plan, map, slice, view), (3) the map of space usage based on time (morning/afternoon, night, other important moment/time), (4) the elements of used space utensils (who uses it, what for and where it is used), (5) building appearance, typology of building.

Kampung Pompa can be reached from the main access of northern side of Kauman Street. On the right side of the road, the entrance to the village is a small alley of 2.5 meter width which becomes the main access to kampung Pompa. There are buildings in closed row formation that have very limited size: no front yard, a mixture between modern and traditional style. It shows the housings of common people transforming into a more modern way of life.

One of the traditional houses that seems to be well maintained is a Javanese traditional symmetrical façade covered with house roof of "pelana" (horse saddle) and is completed with three specific doors, little terrace along the front side with leveled floor and no fence. It is used as a classroom for Qur'an School for Children. In front of this house lies the most dominant building, "musholla" (little mosque). "Musholla" is used not only as a place for religious meeting but also as a place for social meeting.

There are a household regularly activity inside this place. The commerce activity is held from morning to the afternoon, in which the activity of TPA is held twice a day that are one in the morning and one in the afternoon. In the afternoon, at around $3 \mathrm{pm}$ (after Azhar time), Pompa alley starts to get more crowded (Fig. 5). The non-permanent food vendors start to get position. The Quran teachers start to come. People usually come on foot or by motorcycle parked on the corridor of the alley. Subsequently, the little students (santris) come to the alley together with the parents by using motorcycle or by him/herself in green color uniform, which is the characteristic of Javanese Islam, the taker uses terrace and others to chat while 'iqro" learning is started. The TPA is an original education model of Kauman that developed from Pondok Pesantren (Moslem boarding school). Although both of them controlled by different management, but 
sometime they make a certain collaboration to organize a big event of religious.

It also possesses high intensity of social relationship. In the particular time upon the execution of the Children Quran School, this space could be altered as a waiting space (semi private) by setting benches. It is also happened when one of the citizens holds ceremonial party; the place becomes quest-welcoming space. The insight has become convention through the citizen, because of the limited space dimension and high tolerant value. Upon such a way, the perception of tolerant values is biased upon the way of view of the space management.

The classroom building of TPA previously was traditional house built in 1920s (Fig. 6). It was belonged to the old Islamic teacher named Kyai Ridwan. At that time Kyai Ridwan taught Quran at the guest room of his house. He also taught in the Langgar (small mosque) in front of his house.

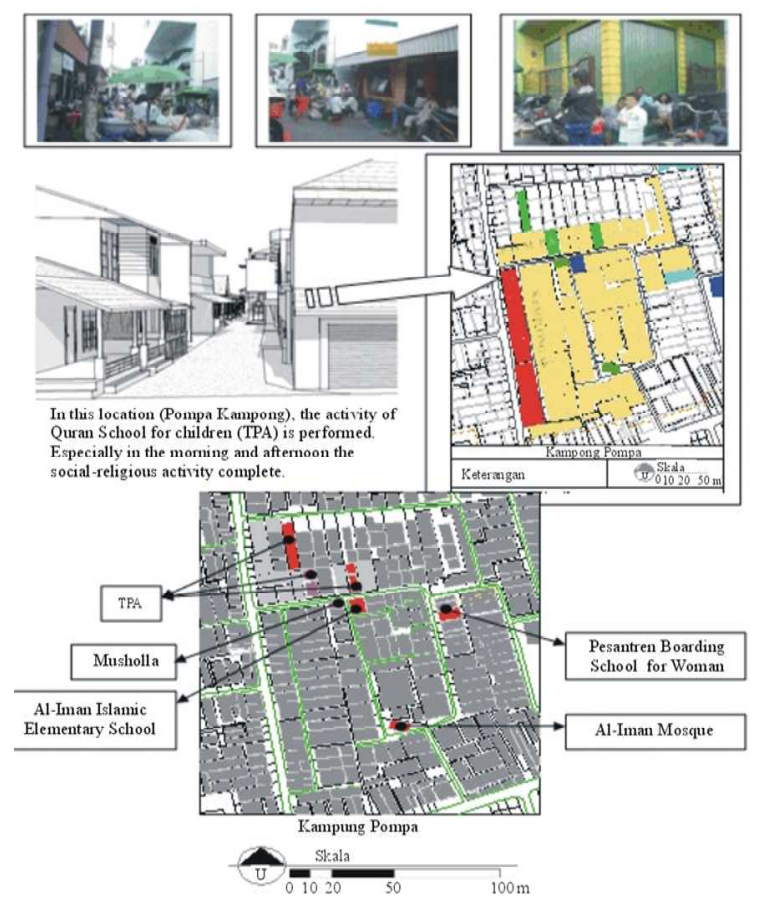

Fig. 5: Situation of Kampong Pompa Kauman when the TPA (Qur'an Children School) was occupied. The space enclose TPA became jam-packed by supporting activity just like: parking, informal trading and play ground. Space symbiosis was occurred between public space and private space. People surrounding the TPA contributed their terrace (private space) to support this activity. It connote to the charity space
Indeed for this phenomenon, Kyai Ridwan educated the useful religious knowledge to students (santris). For this situation he didn't ask to be appraised materially, but he believed that will accept a big reward only from God Allah. He got an advantage of the extended space to support the activity, it made an easy controlling. He also could manage knowledge transfer activity of Langgar from his own house. In other side the Langgar got the life educational from this activity, the society get a knowledge to develop their mental cognition. In 1985 s, the building sold to the success rich-trader and at the end of 1989s lent to the TPA management.

The result of the research founds 11 themes that is classified into 2 concepts (Table 1 ).

\section{The concept of space for charity:}

Teaching important knowledge: There are various types of school based on Islam in kampung Pompa, such as: Qur'an school for children, Islamic Kindergarten School, Islamic Elementary School, "Madrasah", Islamic Junior High School, "Pondok Pesantren" (Islamic School in which students live in the dormitory during their period of study).

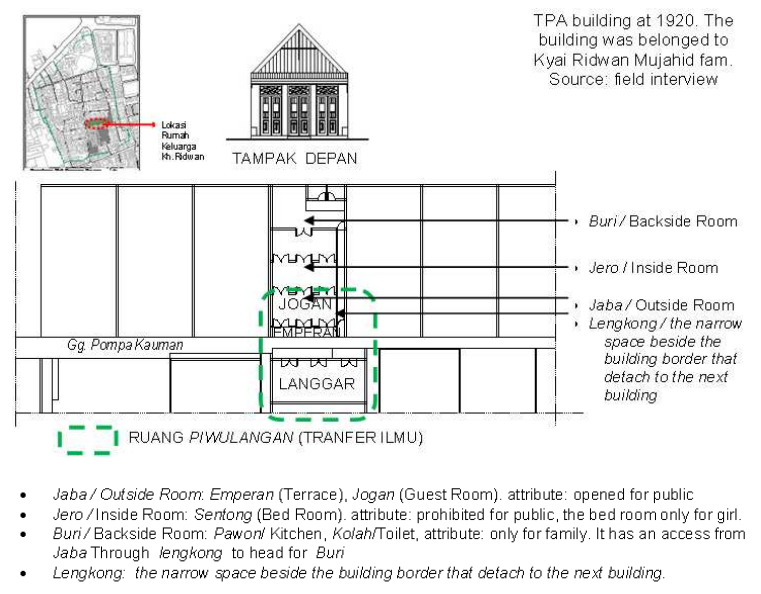

Fig. 6: TPA building for the first period 1920s. At that time the building was a house of Islamic religious teacher (Kyai) Ridwan Mujahid. He also taught Islamic principle in his guestroom. This was the 'blessing house' because people believed that God Allah will bless to the space that used to spell God's name always. In front of the house there was a musholla/langgar. The symbiosis between guestroom and langgar (green border) extended space of Islamic theology transfer. In this case the relation of both of them not only point to symbiosis, but also connoted space for charity that contributed from people to religious activity 
Am. J. Engg. \& Applied Sci., 3 (3): 576-587, 2010

Table 1: The themes and concept of children Quran school (TPA)

\begin{tabular}{|c|c|c|c|}
\hline Theme & Attribute & Idea & Concept \\
\hline The easy controlling space & To organize the limited space of high intensity & space using optimally & Social intensive $\mathrm{sp}$ \\
\hline Space of teaching important knowledge & To contribute the religious knowledge & Religious belief to get award from God & Space for charity \\
\hline House for supervisor of religious activity & To contribute the private space & Religious belief to get award from God & Space for charity \\
\hline Division of function & To organize the limited space of $\mathrm{l}$ & Based on space using optimally & Social intensive space \\
\hline an's organization & To organize community & Maintain Kauman & Self conservation \\
\hline uational space & high intensity & Based on & Social intensive space \\
\hline e of space for relig & To & ward from God & Space for charity \\
\hline Bequeathed Space ('Amanah' Space) & To contribute the space for religious activity & us belief to get award from God & Charity space \\
\hline Santri route alley & To contribute the space for religious activity & Religious belief to get award from God & Space for charity \\
\hline Space for santri to teach & To contribute the religious knowledge & Religious belief to get award from God & Space for charity \\
\hline
\end{tabular}

Those schools teach both formal curriculum and religion based curriculum to the children. Meanwhile, the teaching of Islam for adult learners is called Majlis Taklim. Majlis Taklim is held once in a week and is led by local teacher (kyai/ustadz). This is the manifestation of Islam that suggests teaching beneficial knowledge to people so that they get reward from God, eventhouh they have passed away.

House for supervising the religious activity: In kampung Pompa, the site for educational building is located in the middle of line of houses. The educational building of Qur'an School for Children (TPA) seems to scatter; two buildings functioning as separated class rooms and one building is located in Gang Buntulan. (Buntulan alley). The house of the head of Qur'an School for children (TPA) is situated right in front of the TPA's class room. The buildings there are facing each others that it provides two advantages: (1) easy to complete controlling, (2) TPA gets extra additional space to support teaching and learning process (Fig. 7).

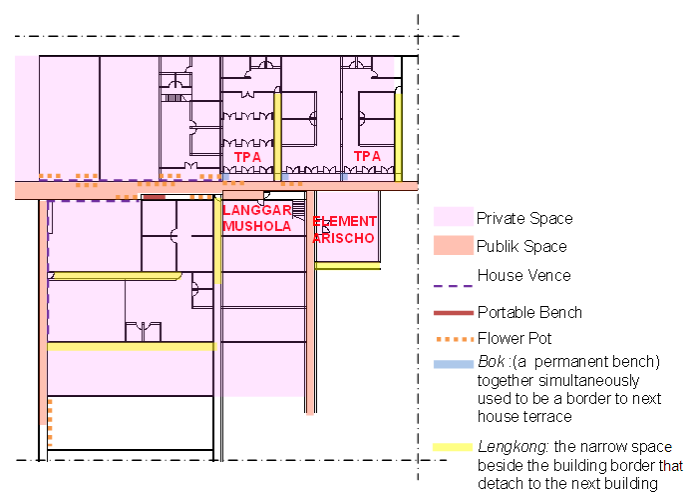

Fig. 7: Qur'an Children School (TPA) Kauman at the present time. Since 1985 the Kyai Ridwan's house was sold to the Kauman's rich trader then, the building was submitted as a wakaf (donation for religious purpose) to be used for religious education institution (TPA). The trader wish, that this this charity reward from Allah would be given to them, it meant that a transitory world that was beyond ivestment
The space controlling system is applied by considering limited space, spontaneous construction and social participation. Hence, the house of Kyai/Ulama (Moslem leader/priest) possesses many roles not only as a dwelling but also as a place to manage the organization and institution. The Kyai/Ulama concerns more on the intention to do good deeds rather than the performance of his house (Fig. 5).

The use of space for religious activities: There has been a convention in kampung Pompa upon the use of space for religious activities. The intense religious activities is not comparable to the limited spaces that the people living in kampung Pompa use public spaces like alley for many religious activities. Even the private spaces of the neighbors like house terraces, door steps, benches and short fences are used by the community to support the religious activities. The community attitude is based on the thought that contributing material property for religious activities is a charity and also a religious good deed (Fig. 7).

Route of santri: In the narrow Pompa alley, everyday a group of female students of Islamic traditional boarding school (Pondok Pesantren) pass by the alley while, sometimes, speaking softly the Quran Ayah. It is routine activity of santris, indeed they want to go to the teacher's house in the next Kampong Glondong for counseling the lesson of memorizing Quran. Within the afternoon, locate in Kampong Pompa, there are also little santris using green Moslem costume, they are students of TPA. Since the TPA building is inside the alley side by side with houses, it makes them use alley space like a playing ground as well as waiting space. Here this situation, terrace-alley of row house, turns to be multi-functioned opened space corridor.

Space for santri (students who learn about Islam) to teach: Many graduates of pondok pesantren (Islamic School in which students live in the dormitory during their period of study) in kampung Pompa decide to stay longer in order to become an Islamic teacher (ustadz). 
Several female students are also seen walking in the alley while reciting the verses of the Holy Qur'an. Some of them marry Kauman men. Then, the couple continues the tradition to teach Islam to the society, especially to their children. For them, the low salary of being an Ustadz is not their biggest concern, but the belief of the reward from the God that matters.

Bequeathed space (Amanah): Bequeathed space is a space entrusted by the community to be used mainly for good deeds. There are some spaces given for centre of social-religious activities, such as:

- The Madrasah Building of Butulan is a bequeathed building established in 1960. It had been abandoned since 1990. However, in 2002 the building was used by Islamic kindergarten school while waiting for its building being renovated. In 2009 , the building was used by local Islamic preschool

- Opened space in kampung Pompa nearby the Qur'an School for children is contributed to extend the activities of the students. The open space includes: open alley, a terrace of a borderless house used as a play ground for children or a transit for the parents and students

The concept of social intensive space: A social intensive space is a limited area used for many settling activities of high intensity. A limited space apparently has the capability to cover many mass activities within high usage frequency and qualified activities experienced by the society. Here, the prominent activities performed by the community are (1) socialcultural activity, (2) religious activity (3) economic activity.

Easy controlling space: In kampung Kemplongan of Pompa, the trader lives in the house behind the store to control household activities. Therefore, trader can do two things at the same time, working in a store and taking care of household activities. Another advantage from this system is cost saving. Here, good location determines easy controlling system. Furthermore, the house of Kyai (Moslem leader/priest) is located inside the kampung, nearby Qur'an School for children (TPA) that enables Kyai to supervise the activities running in the houses. Hence, the Kyai recognizes when there is educational problem needed to be solved immediately.

The division of function: There are two characteristics of the activities held in kampung Pompa: (1) domestic activity, an activity organized by the Kauman and intended for the Kauman (2) external activity, an activity held by the older generation of Kauman people in which the benefit is given to both the people of Kauman and others living outside of Kauman dwelling. In kampung Pompa, the separation of domestic and external function only works for economic activities, but not for social-religious activities. The external economic activity takes the main corridor in order to get an easy access for four-wheel vehicles. On the other hand, domestic economic activity can be found inside the kampung. It does not direct access to the main street. Thus, the separation of zone in Kauman is not based on domestic and external characteristic of an activity but rather on the economic factor. Nevertheless, the inaccessible location has a great advantage for the social-cultural function since its originality is protected from the external influences.

The situational space: The high intensity of such activities in Kauman and the fact of the limited spaces available require spatial flexibilities to various functions of certain needs. There are three spatial characters (Hall, 1990; Rapoport, 1990):

- Fixed space, a space which has a rigid shape, constructed by permanent elements with the main function attached, such as: house, mushola (small mosque), Qur'an School for Children (TPA), mosque. The house is built as the result of cultural convention in the community. It involves the size of the building, the shape, the material/technology and the function attached

- Semi fixed space, a space having permanent elements (wall, window, etc) but using nonpermanent materials and size. The function is flexible based on activities held, for example; a guest room with the main function to welcome and receive visitors, yet, it can be transformed into a room for reciting the verses of the Holy Qur'an and other social functions

- Non-fixed space is a space having non-fixed elements and flexible shape that can accommodate different functions, for example; a mass religious meeting requires a wider space, however, considering the lack of space, the people use portable tent to cover public spaces from direct sun light. Here, the main function of the alley as a public space for transportation is transformed into a meting room, commercial room, play-ground for children, security space, etc 


\section{DISCUSSION}

Spaces in kampung Pompa are constructed in systematical structures which represent the needs of the community (appropriated space). Each part has status and roles that reflect the owner himself. The highest hierarchy among the buildings here is Qur'an School for children, which is located inside the kampung. This building was formerly used by a Kyai in early 1900s as a place to live in and to teach the religion of Islam. In 1980 , the house was owned by a trader and later on, he donated the house to be used as Qur'an School for Children (TPA). Apparently, the people in the kampung believe that it is a blessed house. Thus, they determine to take care and preserve the building. There is a musholla (small mosque) opposite the building led by a Kyai who is well respected by the people. The Kyai lives next to the musholla. In the last two decades, the function of an educational institution gradually developed and significantly replaced the dwelling function. This matter shows a relationship between time and place. According to Tuan (1977), time is considered as the flow of a movement and place is a pause. Here, the ownership of a building may change into a linear static direction due to time movement or human movement, while the building function movement has a circle-static-direction. After having been used as business function, the building function returns back to the first function; Qur'an education. Hence, the power of religious aspect can be used to control the function movement of the building (Fig. 8).

In order to overcome the problem of limited spaces, a space symbiosis is conducted. Interaction among spaces is developed by borrowing spaces scattered in the area, for example: the space located in between Qur'an School for children and the alley, musholla and the surrounding houses. Houses located in Pompa alley are the dwellings for ordinary people and Kyai/ustadz. The people living there fully support religious activities initiated by Kyai. They respect Kyai as the leader of the community.

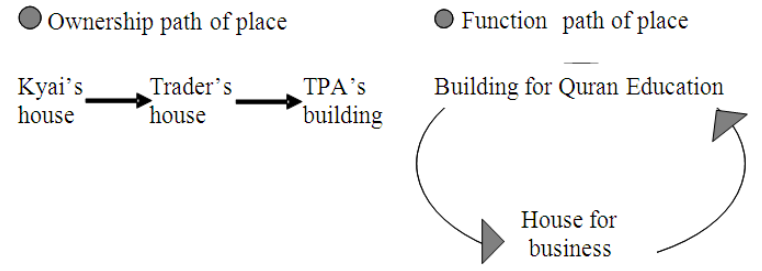

Fig. 8: The relationship between time and place in Kampong Pompa Kauman. The Religious aspect power should able to control the function movement of building
The commercial area is located in the main corridor as it is the easiest access for public. It functions as the main contributor for any religious activities. The houses of traders lie in rows behind the stores. Some of the houses have been renovated in modern style while others still maintain the traditional style that reflects a tight functional relationship, managerial relationship and status. The houses of traders in kampung Kemplongan even exclusively secluded from the environment as the result of the growing number of traders occupying the area. However, both traders and the surrounding dwellers never have significant conflict since they have a good social relationship. Gradually, the structure of space at kampung Pompa is shaped on the basis of the dwellers' needs influenced by religious doctrine and commercial thought.

According to Lefebvre (1998) appropriated space is defined as a spatial practice in which nature has been modified in order to satisfy and expand human needs and possibilities. Appropriated space of kampung Kauman can be clearly seen from its spontaneous and unplanned development. In early 1870s, the local government sold a wide range of this area to several Landlords. The Landlords then rented it to the outsiders. In 1930s, there were several spots of commercial function on the main road along with the establishment of "Pasar Johar" (Johar market) by the Dutch government (1937). Each part of the neighborhood developed well accommodating the needs of the community. The new comers of the religious leaders (Kyai) rented a certain part of the area and built a house to live in which later on was also used as a place to teach the religion of Islam. Here, the function of space developed from social-household to social-religious function. The traders rented strategic location in the main corridor and built stores for their businesses. Next, they bought the area nearby their stores and developed bigger businesses.

Modification of space conducted by Kyai mainly referred to the needs of religious propaganda. Fortunately, this activity was also supported by the people living in the area. The traders, with the power of their capital, also modified their properties regarding the function of space as commercial spots. They also gained support from the neighbors because of the good social relationship

The situation of both appropriated space for religion and appropriated space for commerce has created the concept of social intensive space. The concept of social intensive space is a limited area used for many settling activities of high intensity. It has the capability to cover mass activities of high usage frequency and of qualified activities experienced by the 
community. Community activities here includes: (1) social-cultural activity, (2) religious activities and (3) economic activities:

- Easy controlling. A religious leader manages the institution from his house located just opposite the institution. A trader lives in a house behind the store so that she/he, at the same time, can control both the family and the business

- A Separation of kampung zones. It is determined by the economic factor, not the accessibility factor. Commercial/business activities occur on the main road, while domestic function occurs behind the main road and inside the kampung, further; the external function is seen through educational and religious institutions

- Situational space. Situational space is a space to accommodate high intensity activities within limited spaces. In order to meet the need of wider spaces, the dwellers organize such strategy of space usage and space elements. First of all, the dwellers utilize a fixed space, like: a house, musholla, institutional buildings, mosque, etc. Then, the dwellers use semi fixed space to widen the space by opening the temporary dividing wall. To accommodate mass activities (religious meeting for hundreds of participant), they utilize non-fixed space. It is actually an open space or alley nearby fixed spaces that is used by removing moveable elements-flower pots, benches-and setting up a tent to cover this open space

Lefebvre (1998) also explains a cosmic space which contains energy or force. In kampung Kauman, the cosmic space contains energy generated through the teaching of Islam that motivates the people to do good deeds based on the religious doctrine they believe in. Consequently, the community contributes the knowledge of Islam to other people, donates some money to support religious activities and contributes public and private space to support religious activities which is believed to provide good benefit in the world and beyond.

The concept of Space for Charity emerges systematically based on the faith to obey religious doctrines. As long as the donated space is used for good reasons, they believe that they will have rewards from God. Qur'an and Hadist suggest all Moslem to do this.

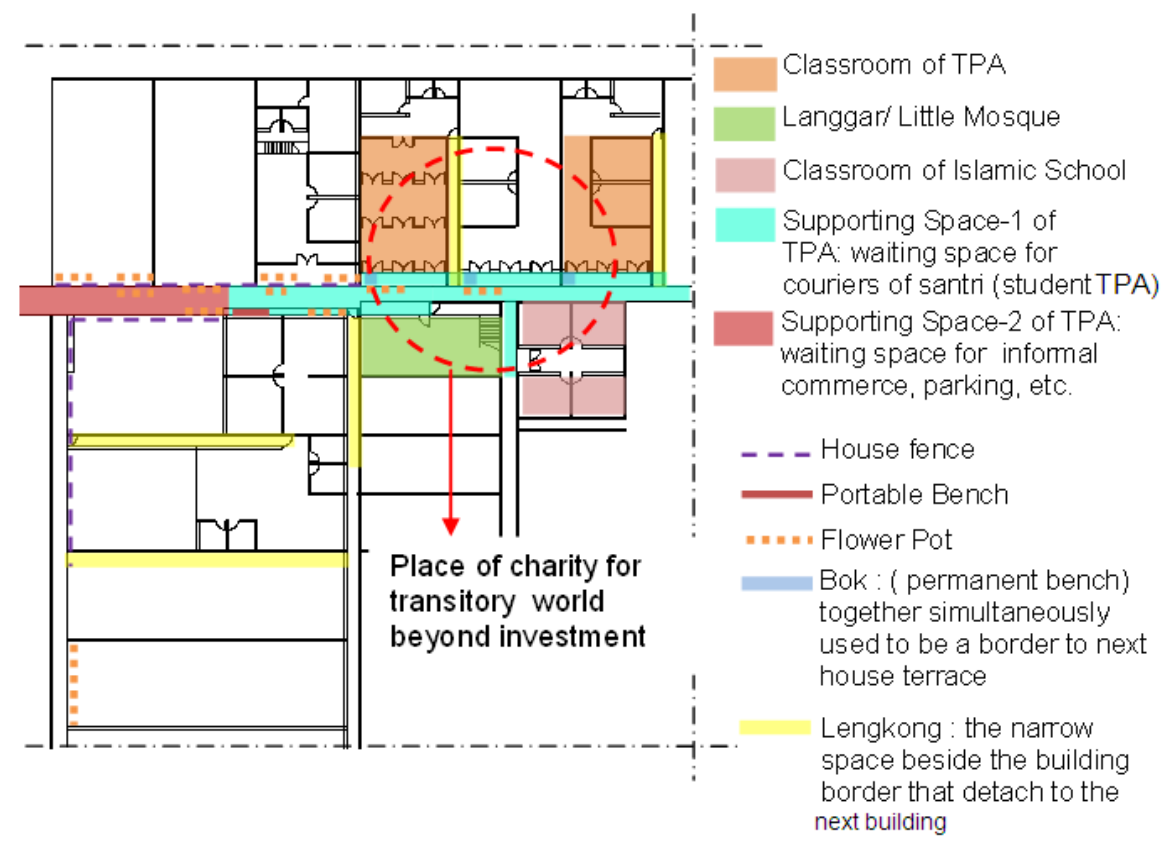

Fig. 9: A space for charity in kampung Pompa. The building of Qur'an School for children is donated by one of Kauman people through the system called wakaf (donation for religious purpose). Kyai/Ustadz is willing to transfer the knowledge without expecting financial profit. The dwellers donated private and public spaces to support all activities at Qur'an school for children. They believe God will give them blessing and reward 
Space for charity is a tradition that has been preserved since the establishment of the kampung. The tradition is passed on from the older generation to the younger one. It includes material and immaterial aspects as seen in Fig. 9:

- Contributing the private space: A successful businessman donated a house for a religious institution. A religious teacher donated part of his house to manage religious institution. An ordinary person donated his terrace and his private space to support the teaching of religious doctrine managed by his next door neighbor

- Contributing the public space: he community determined convention toward a space for charity. They give permission on the use of their front yard and the alley surrounded their houses to support religious activities-play ground for the students, waiting room for the parents who pick up their children and social meeting

- Contributing the useful religious knowledge: A religious leader established religious institution to spread religious doctrines on the basis of charity. A teacher teaches useful religious knowledge

This concept represents an ideology of the strong Moslem adherents to disseminate the religion of Islam and to be responsible toward the next generation of Moslem people to have the quality of a Kaum.

\section{CONCLUSION}

The research discovers 11 themes related to the original culture. The meaning of symbol works upon three phases (1) physical (2) function and (3) idea/point of view. The significant concept discovered in this research is a 'space for charity' in which contributing space for the advancement of religious education will give them abundant reward from Allah (God). The second one is 'social intensive space' as a strategy to maximize the limited spaces for high intensity usages. It combines social-cultural-religious aspects and economic aspects encountered by the dwellers in their daily routines. For the Kauman, a strong Moslem adherent should accommodate those aspects as the result of social relationship. The relationship between time and place should control the changing of building function. Kauman is also a cosmic space which contains the energy or power to generate and control terrestrial energy as well as the celestial energy to reach the equilibrium of both energies. The structure of kampung Pompa is centered at the musholla and its surrounding. It is the center of social-religious activities: Qur'an school for children, Islamic Elementary School and musholla (small mosque) as a place to perform religious meeting.

Kyai holds an important role in term of appropriate space in Kauman. Space modification is applied in private area (house) so that it can also be utilized as a place to teach religion. Public spaces like musholla, the buildings next to the alley/main road are also modified to support the religious activities. It is managed by applying space symbiosis and space feature element organization (fixed elements, semi-fixed elements and non-fixed elements) that enable the changing of space (size, form, function, territory) depending on the events and needs. For the Kauman, the knowledge delivered by Kyai has given them motivation to conduct good deeds, which is also an indicator of the occurrence of energy in the cosmic space.

Traders also hold important roles in shaping the structure of kampung Kauman Pompa. They modified the commercial zone and the housings for religious activities. They also prevented kampung Kauman from the coming of outsiders. For them, a house functions not only as a place to live in but also as an office to run economic activities and to expand their businesses.

Appropriated space in Kauman not only represents a modified space situation to accommodate social, economic and religious needs but also as a space to express their existence as 'Kauman' people who hold the mandate as religious leaders.

\section{ACKNOWLEDGEMENT}

This study substance is part of the dissertation entitled "Kauman: The Residing Tradition of Moslem Community in the Downtown of Semarang" by Atiek Suprapti and is supervised by Prof. Eko Budiharjo, Dr. Galih Widjil Pangarsa dan Prof. Dr. Nurdien $\mathrm{H}$ Kistanto. We are grateful to especially: Prof. Dr. Gunawan Tjahyono from Indonesian University for all comments and suggestions and Prof. Dr. Julaihi Wahid from University Sains Malaysia for information.

\section{REFERENCES}

Atkinson, P., A. Conffey, S. Delamont, J. Lofland and L. Lofland, 2008. Handbook of Ethnography. Sage Publication.

Denzin, K.N., 2009. Handbook of qualitative research. Pustaka Pelajar.

Geertz, C., 1973. The Interpretation of Cultures: Selected Essays. 1st Edn., Basic Books, Yogyakarta, ISBN: 10: 046503425X, pp: 470. 
Hall, T.E., 1990. The Hidden Dimension. 1st Edn., Doubleday, New York, ISBN: 0385084765, pp: 217.

Jessor, R., A. Colby and R.A. Shweder, 1996. Ethnography and Human Development. 1st Edn., The University of Chicago Press, Chicago/London, ISBN: 10: 0226399036, PP: 530.

Lefebvre, H., 1998. The Production of Space. 1st Edn., Blackwell, Cambridge USA., pp: 454.

Rapoport, A., 1977. Human Aspect of Urban Form. 1st Edn., Franklin Book Co., New York, ISBN: 10: 0080179746, pp: 438.

Rapoport, A., 1990. The Meaning of the Built Environment: A Nonverbal Communication Approach. 1st Edn., University of Arizona Press, Arizona, ISBN: 10: 0816511764, pp: 253.
Rapoport, A., 2005. Culture, Architecture and Design. 1st Edn., Locke Science Publishing Co., Inc., USA., ISBN: 10: 0974673609, pp: 138.

Spradley, P.J., 2007. Metode etnografi. Tiara Kencana. Suprapti, A., 2009. Permukiman muslim berbasis kemasyarakatan sosial studi kasus kauman semarang. Fakultas Teknik Universitas Diponegoro.

Tuan, Y.F., 1977. Space and Place the Perspective of Experience. 1st Edn., University of Minnesota Press, Minnesota, ISBN: 10: 0816608083, pp: 235. 